\title{
Chlormethine Gel for the Treatment of Skin Lesions in All Stages of Mycosis Fungoides Cutaneous T-Cell Lymphoma: A Narrative Review and International Experience
}

\author{
Larisa J. Geskin · Martine Bagot · Emmilia Hodak · Ellen J. Kim
}

Received: February 26, 2021 / Published online: May 21, 2021

(C) The Author(s) 2021, corrected publication 2022

\section{ABSTRACT}

Mycosis fungoides (MF), the most common form of primary cutaneous T-cell lymphoma, is a disease typically with an indolent course that is initially characterized by localized patches and plaques. In the early stages of the disease, treatment involves skin-directed therapies (SDTs) such as topical corticosteroids and retinoids. Chlormethine gel (also known as

L. J. Geskin $(\varangle)$

Department of Dermatology, Columbia University, 161 Fort Washington Ave, 12th Floor, New York, NY 10032, USA

e-mail: ljg2145@cumc.columbia.edu

M. Bagot

Department of Dermatology, AP-HP, Université de Paris, Hôpital Saint-Louis, Paris, France

e-mail: martine.bagot@aphp.fr

E. Hodak

Division of Dermatology, Rabin Medical Center, Beilinson Hospital, Sackler Faculty of Medicine, Tel Aviv University, Tel Aviv, Israel

e-mail: ehodak@clalit.org.il

\section{E. J. Kim}

Department of Dermatology, Perelman School of

Medicine at the University of Pennsylvania,

Philadelphia, PA, USA

e-mail: ellen.kim@pennmedicine.upenn.edu mechlorethamine) was the first SDT purposely developed to treat MF and is currently endorsed by international guidelines for the treatment of adult patients with MF as a first-line therapy. While chlormethine is an efficacious therapy, its usage may be complicated by the development of cutaneous reactions at the sites of application. Herein, we discuss the supportive guidelines for MF and the suitability of chlormethine as a therapeutic option in patients with MF. In addition, we present realworld experience on the use of chlormethine gel from clinics in the USA, Israel, and France with the aim of demonstrating the efficacy of chlormethine gel in routine clinical practice and outlining strategies that are being used to manage emergent cutaneous reactions. 
Keywords: Chlormethine gel; Cutaneous T-cell lymphoma; Mycosis fungoides; Patient management; Real-world

\section{Key Summary Points}

Mycosis fungoides (MF) is a cutaneous T-cell lymphoma typically with an indolent course that is initially characterized by localized patches and plaques

Chlormethine gel is a therapeutic option recommended by international guidelines for patients with MF skin lesions; a range of retrospective, prospective, and observational clinical data supports its use in all disease stages

While chlormethine is an efficacious therapy, its usage may be complicated by the development of cutaneous reactions at the sites of application

Real-world experience from clinical practice in the US, Israel, and France has shown that chlormethine gel is used as a skin-directed therapy in the first- and second-line setting in patients with earlystage MF and as an adjunctive therapy in patients with advanced-stage disease

The emergent cutaneous adverse reactions can generally be managed through chlormethine gel dose adjustments or the use of topical steroids

\section{DIGITAL FEATURES}

This article is published with digital features, including a infographic, to facilitate understanding of the article. To view digital features for this article go to https://doi.org/10.6084/ m9.figshare.14447193.

\section{INTRODUCTION}

Cutaneous T-cell lymphomas (CTCLs) are a heterogeneous family of T-cell lymphoproliferative disorders, of which mycosis fungoides (MF) is the most common. Early-stage MF follows a slow, indolent course [1], with symptoms present for extended periods of time. Due to the clinical similarity between benign skin diseases (such as eczema and psoriasis) and early-stage $\mathrm{MF}$, as well as the lack of a singular diagnostic test or specific tumor markers, median time between MF symptom onset and biopsy-confirmed diagnosis is 4-6 years [2]. Most patients with early-stage MF have an average life expectancy following treatment but reduced quality of life [3]. Median survival for those with stage III or IV disease is low ( $<5$ years), and $\geq 50 \%$ die of their disease [4-7]. MF treatment goals are symptom control and quality of life improvement [8], as there are no curative therapeutic options aside from allogeneic stem cell transplantation [9].

In this review, we will briefly present the treatment guidelines for the management of patients with MF, discuss the role of topical chlormethine gel as part of the treatment paradigm, provide an overview of the clinical data demonstrating the effectiveness of the gel, and present real-world experience of chlormethine gel usage from four different dermatology practices.

This review is based on previously conducted studies and does not contain any new studies with human participants or animals performed by any of the authors. Informed consent was provided by the patient whose case was included.

\section{CLINICAL MANAGEMENT GUIDELINES FOR MF}

MF treatment guidelines (European Society for Medical Oncology [10], European Organisation for Research and Treatment of Cancer [11], National Comprehensive Cancer Network [12], and British Association of Dermatologists/UK Cutaneous Lymphoma Group [13]) base their recommendations on disease stage [10-13]. 


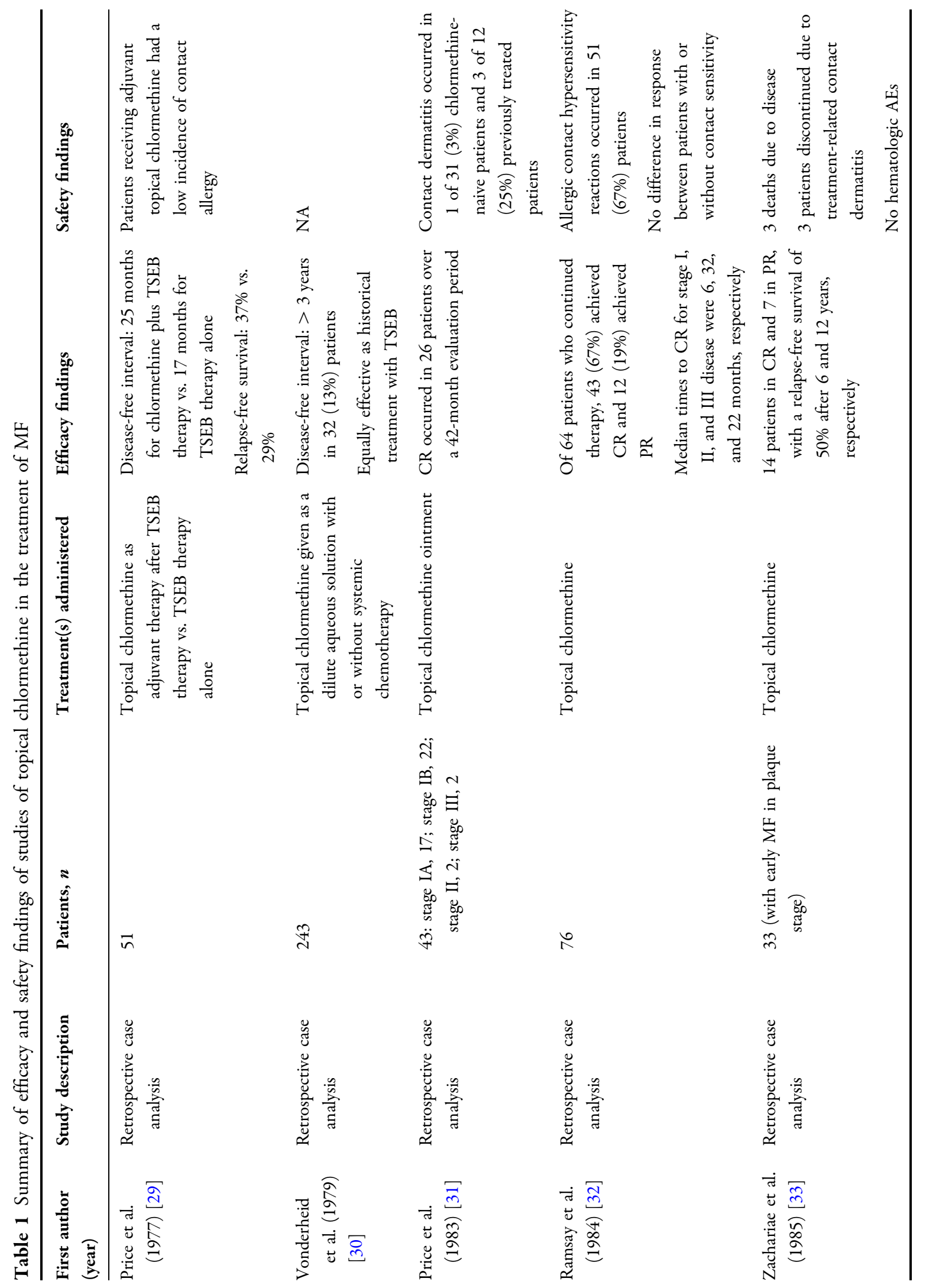




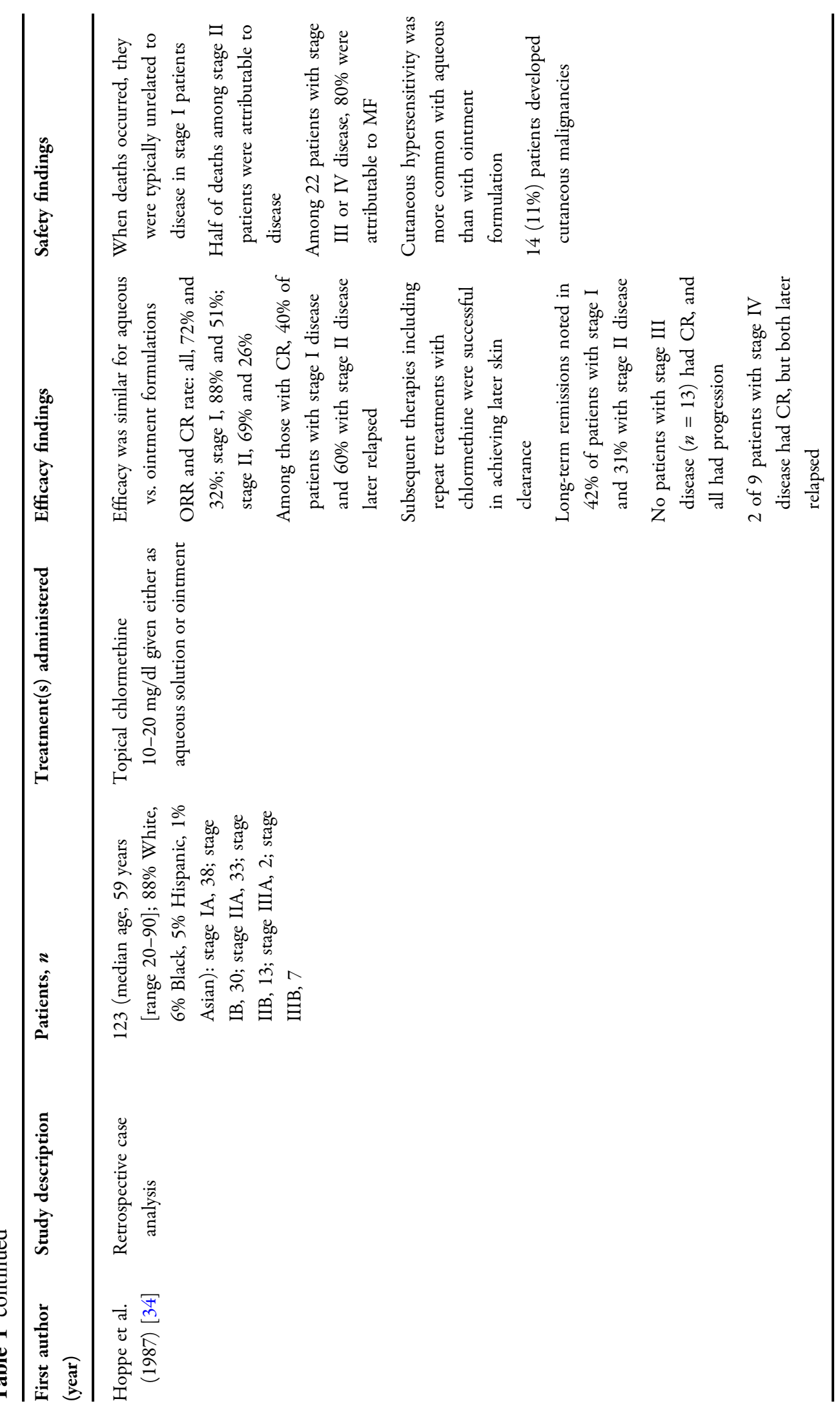




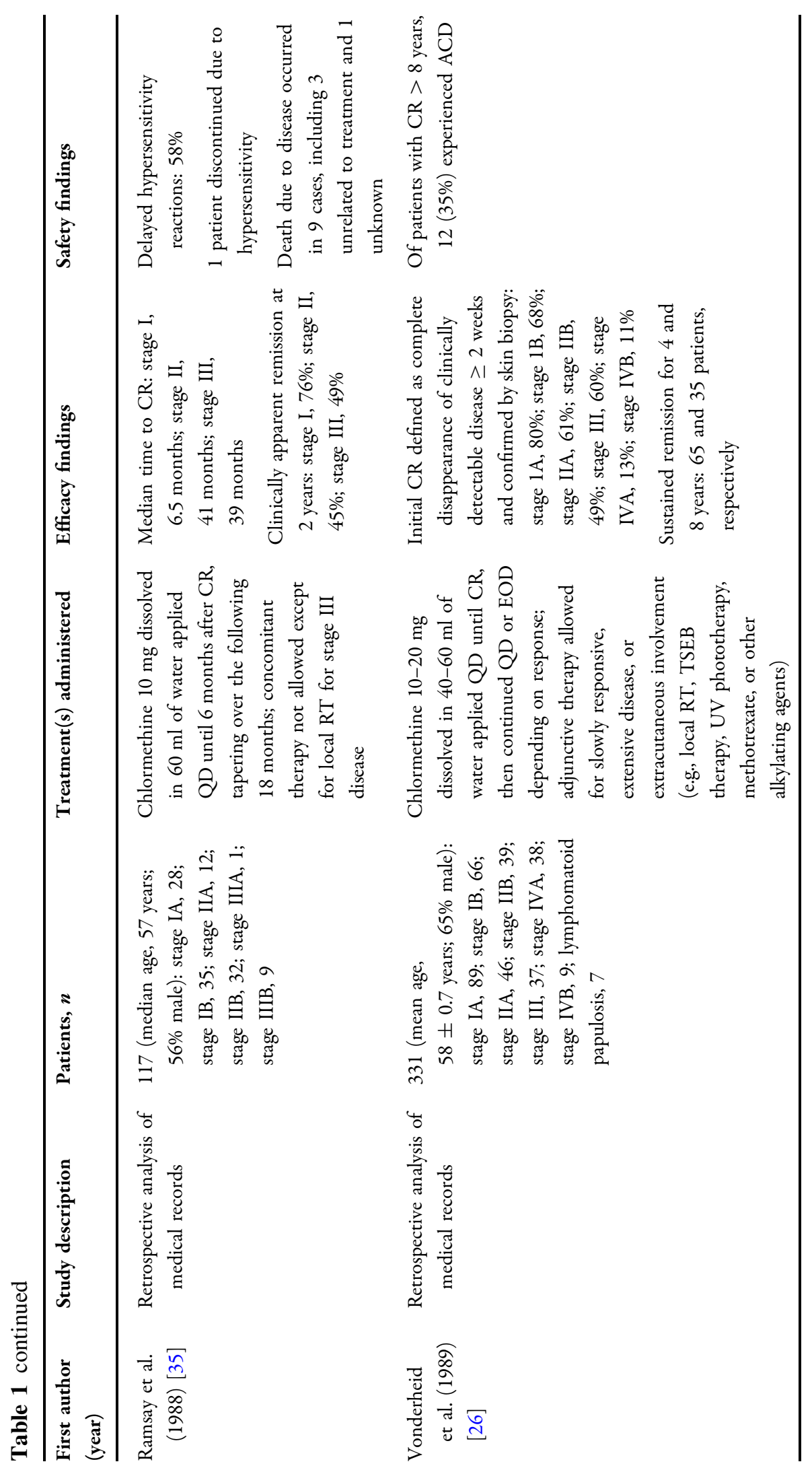




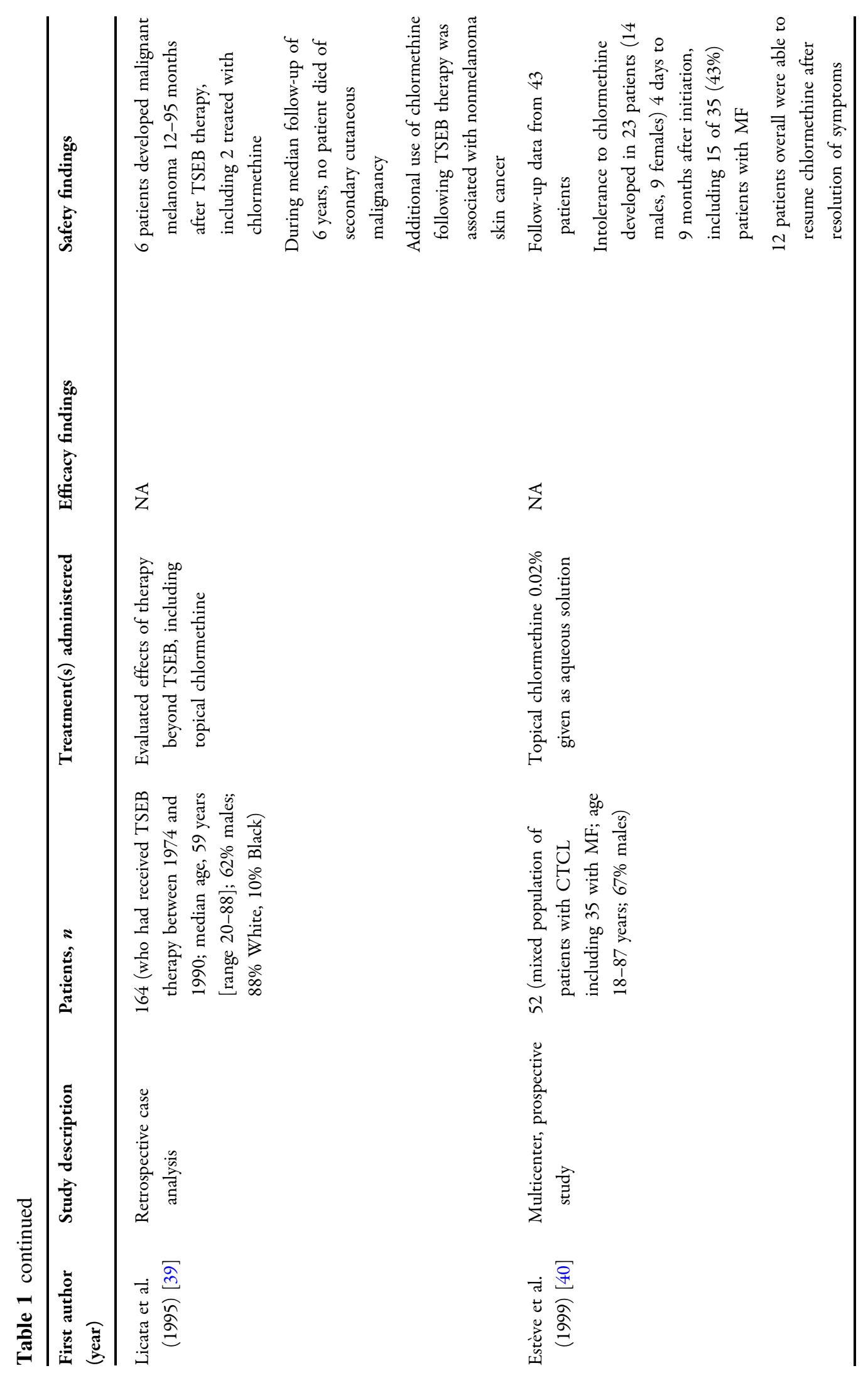




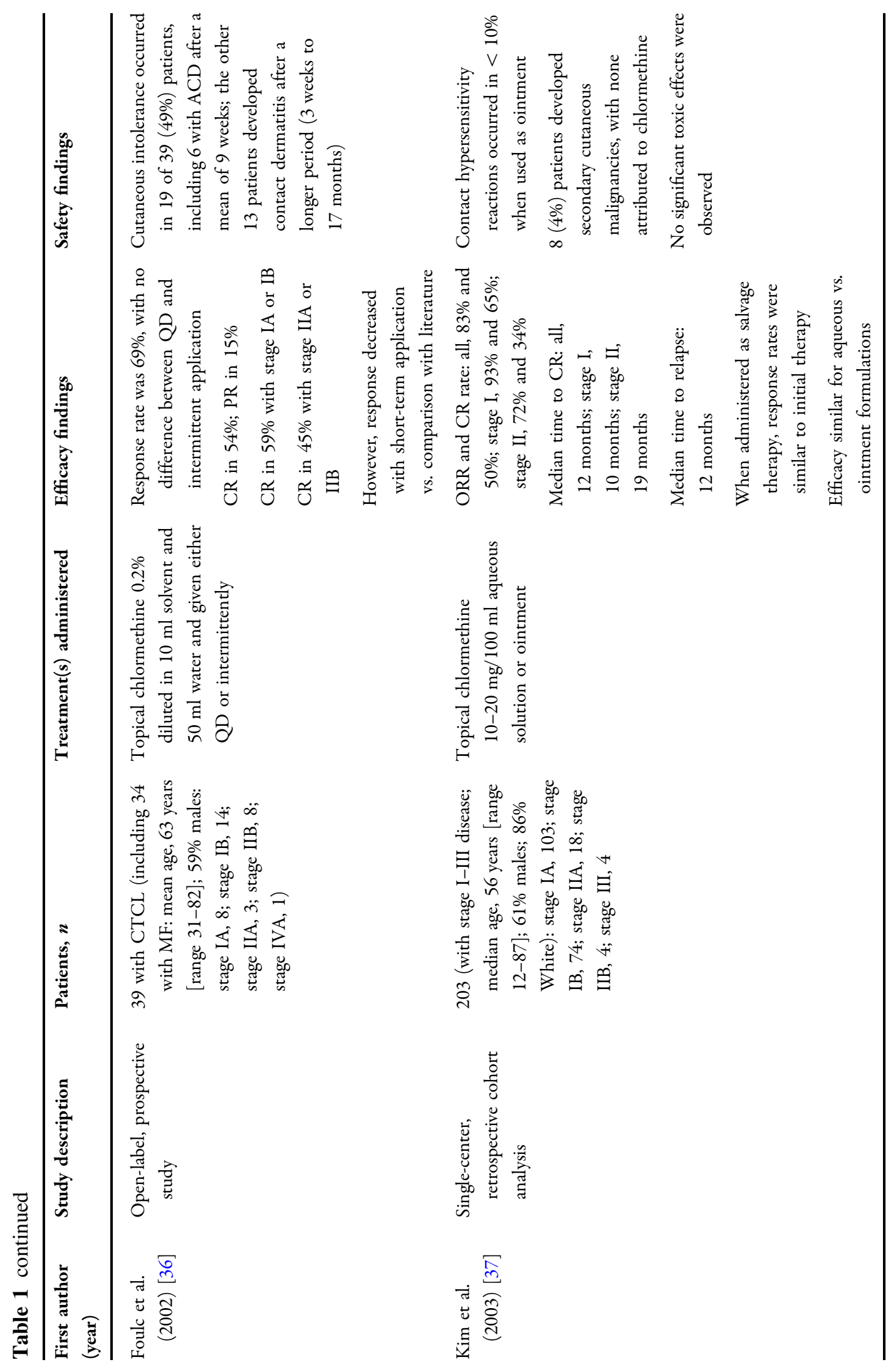




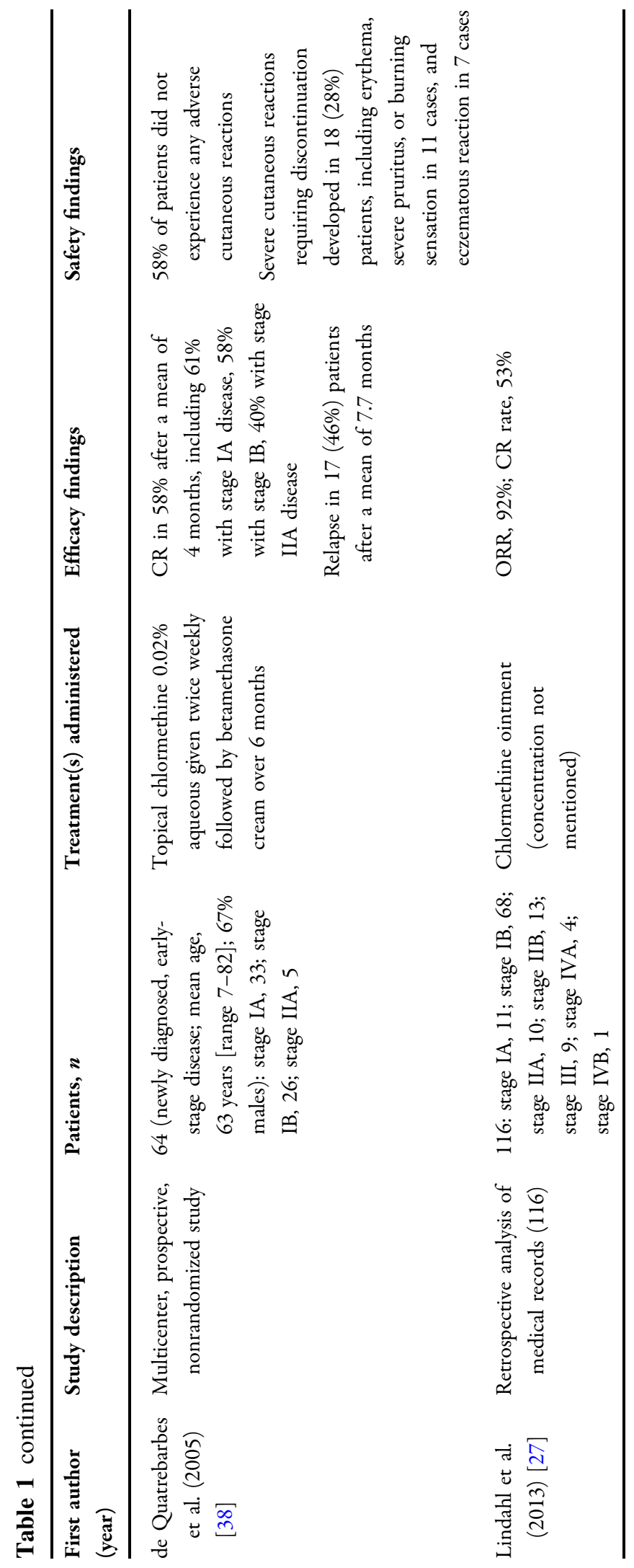




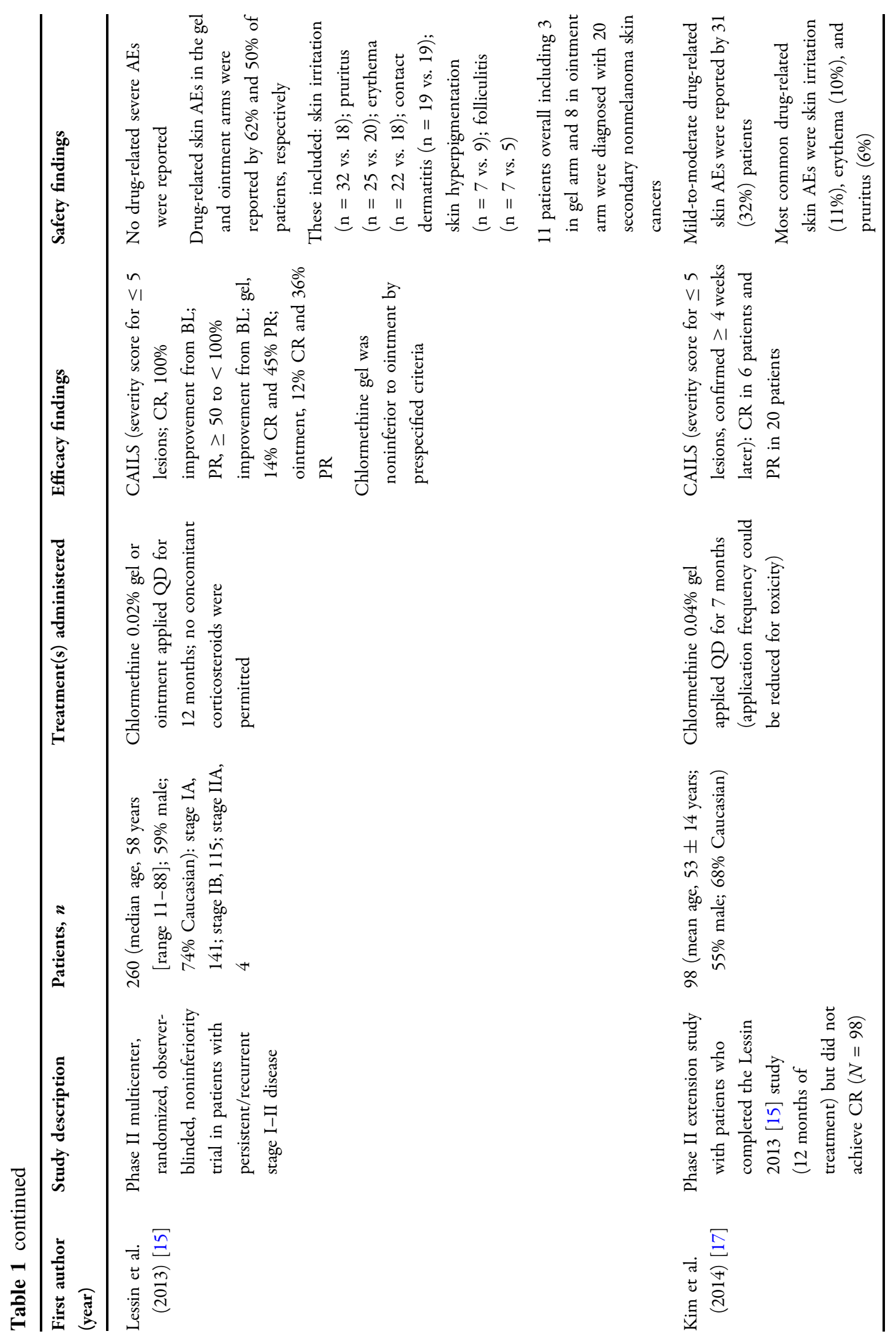




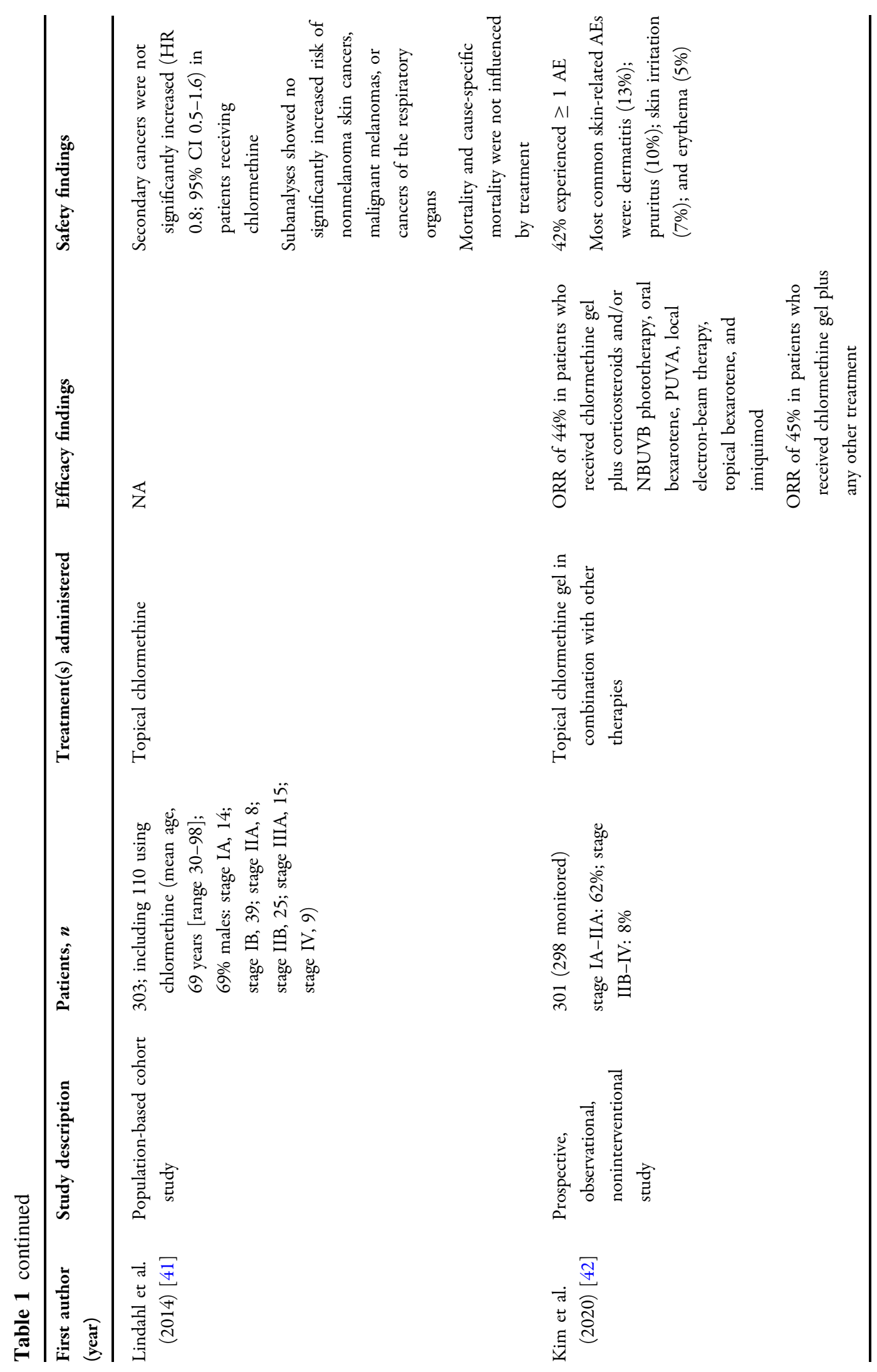




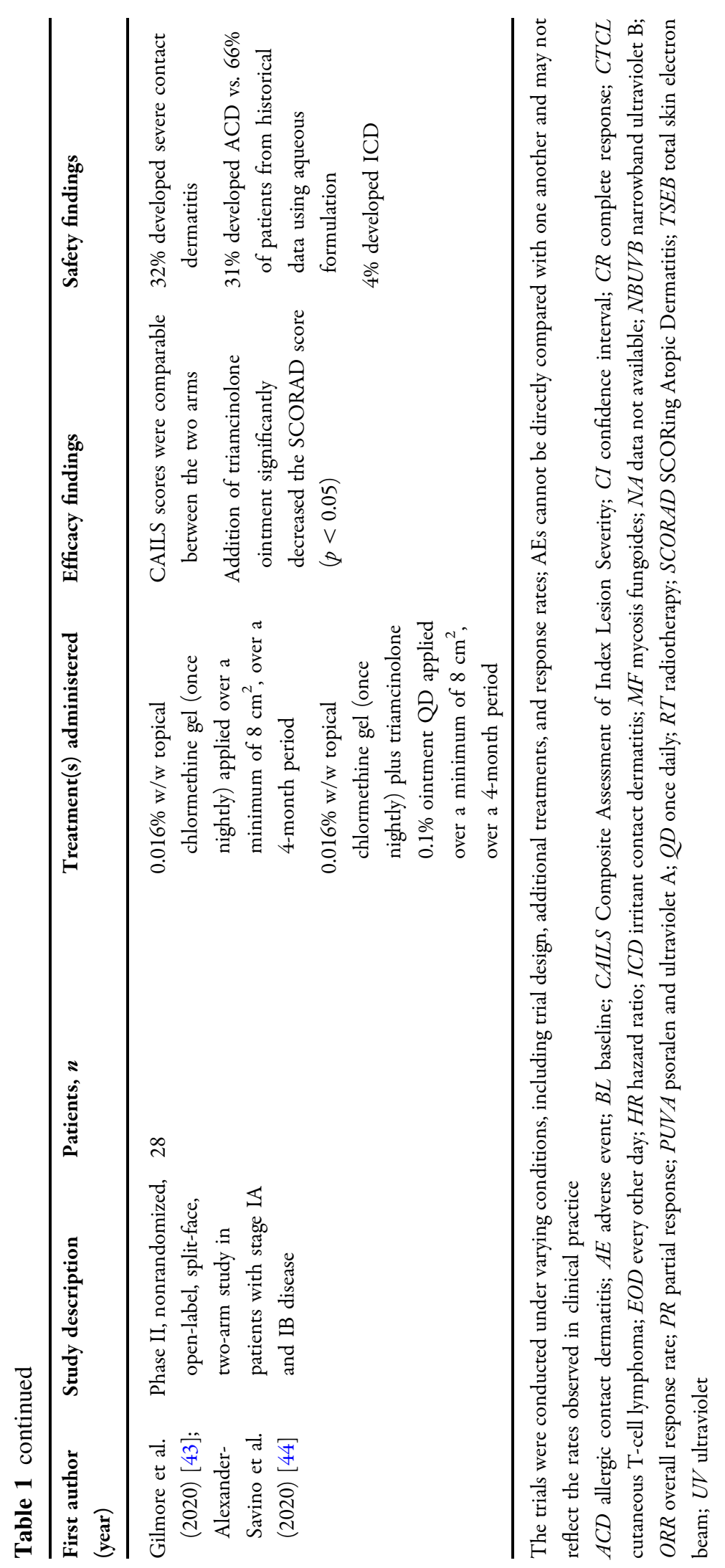


For asymptomatic patients with early-stage MF (stage IA), "watch and wait" is considered an appropriate option. For symptomatic patients, those with adverse prognostic factors (such as plaque stage disease or large cell transformation), or those with extensive disease involvement (stage IB), skin-directed therapies (SDTs) should be initiated. The most commonly used SDTs for treating early-stage MF are topical corticosteroids $[8,14]$, topical chlormethine or retinoids $[15,16]$, and phototherapy; superficial radiotherapy may also be employed. Patients with advanced-stage disease generally receive systemic single-agent or combination therapy with SDTs. Addition of an effective SDT can alleviate symptoms and shorten time to response compared with systemic therapy alone [11].

\section{CHLORMETHINE AS TOPICAL CHEMOTHERAPY FOR MANAGING $\mathrm{MF}$}

All major guidelines recommend the use of chlormethine for first-line treatment in adult patients with MF [10-13]. Chlormethine is a bifunctional alkylating agent that inhibits rapidly proliferating cells by binding and crosslinking DNA strands. The original aqueous and ointment formulations were not approved as a therapy for MF, and it was subsequently developed as a topical gel $[15,17]$. This formulation was approved by the US Food and Drug Administration (FDA) in 2013 for treating stage IA and IB MF in patients who received prior SDT, has been registered in Israel since 2016 (for the same indication as in the USA), was approved by the European Medicines Agency in 2017 for treatment of adult patients with MF [18], and is now available commercially in a number of European countries. Chlormethine gel has been available in France since 2014 under a "temporary authorization for use" program that ended in July 2019, with 876 patients having participated [19].

The chlormethine gel (chlormethine 0.016\% $\mathrm{w} / \mathrm{w}$, equivalent to $0.02 \%$ chlormethine hydrochloride) formulation was designed to maximize efficacy and tolerability. Its nonaqueous nature imparts high stability, and the active solvent, diethylene glycol monoethyl ether (Transcutol $\left.{ }^{\circledR}\right)$, promotes delivery of the drug to the epidermis [20-22], although there is no evidence of systemic absorption of chlormethine following application [15]. Efficacy is enhanced by inclusion of the excipient, Klucel $^{\mathrm{TM}}$ hydroxypropylcellulose (Ashland) [23], which results in a fast-drying, nongreasy formulation with a viscosity that is more likely to remain at the administration site, which makes it easier to apply at home. The intrinsic antimicrobial nature of the active ingredients [24] removes the need for antimicrobial preservatives (which frequently cause skin reactions), thus potentially reducing the risk of allergy, although further investigations are required to confirm this.

Chlormethine may be used as monotherapy in early-stage MF, in combination with systemic therapy in advanced-stage disease [25-27], and as maintenance treatment $[11,28]$. The chlormethine gel label indicates daily application; however, the frequency of application may be reduced according to the patient's needs. For severe skin reactions, treatment should be suspended (in some cases permanently) and upon improvement can be restarted gradually up to daily frequency, if tolerated.

\section{CHLORMETHINE IN MF MANAGEMENT: A REVIEW OF THE LITERATURE}

There is a substantial body of prospective and retrospective evidence underlying the recommendation of chlormethine as a treatment option for patients with MF in all stages of the disease (summarized in Table $1[15,17,26$, 27, 29-44]). These studies have demonstrated that chlormethine is efficacious, with a durable response that may be sustained for up to 8 years in some cases.

The pivotal registration 201 study evaluated chlormethine gel versus chlormethine ointment for the treatment of patients with persistent or recurrent stage I or II disease who received no concomitant corticosteroids. Response rates for chlormethine gel were 
Table 2 Summary of the real-world experience from four centers

\begin{tabular}{|c|c|c|c|c|}
\hline Characteristic & $\begin{array}{l}\text { Penn } \\
\text { Dermatology } \\
\text { Cutaneous } \\
\text { T-Cell } \\
\text { Lymphoma } \\
\text { Clinic, USA }\end{array}$ & $\begin{array}{l}\text { Cutaneous Oncology } \\
\text { Clinic, Columbia } \\
\text { University, USA }\end{array}$ & $\begin{array}{l}\text { Rabin Medical Center, } \\
\text { Israel }\end{array}$ & $\begin{array}{l}\text { Hôpital Saint-Louis, } \\
\text { France }\end{array}$ \\
\hline $\begin{array}{l}\text { Number of } \\
\text { patients } \\
\text { with MF } \\
\text { seen/year }\end{array}$ & $\sim 200$ & $>350$ & 300 & $\sim 320$ \\
\hline $\begin{array}{l}\text { Disease stage } \\
\text { of patients } \\
\text { with MF }\end{array}$ & Mostly early stage & $\begin{array}{l}\text { Ranging from stage IA or } \\
\text { IB to Sézary syndrome }\end{array}$ & Early stage & Early and advanced stages \\
\hline $\begin{array}{l}\text { Chlormethine } \\
\text { gel usage }\end{array}$ & $\begin{array}{l}\text { Early stage: } \\
\text { treatment after } \\
\text { corticosteroids } \\
\text { failure } \\
\text { Advanced stage: } \\
\text { adjunctive } \\
\text { treatment to } \\
\text { systemic } \\
\text { therapies or } \\
\text { other SDTs }\end{array}$ & $\begin{array}{l}\text { For patients with early } \\
\text { stage, skin-limited } \\
\text { disease } \\
\text { Advanced disease: in } \\
\text { combination with } \\
\text { systemic therapies }\end{array}$ & $\begin{array}{l}\text { Second-line treatment in } \\
\text { patients for whom at } \\
\text { least } 1 \text { previous SDT } \\
\text { failed (topical steroids } \\
\text { or phototherapy) }\end{array}$ & $\begin{array}{l}\text { Early stage: second-line } \\
\text { treatment after failure of } \\
\text { high-potency } \\
\text { corticosteroids, mainly } \\
\text { when phototherapy is } \\
\text { not possible or } \\
\text { contraindicated } \\
\text { Late stage: in combination } \\
\text { with systemic treatments } \\
\text { when insufficient effect is } \\
\text { observed on } \\
\text { patch/plaques lesions }\end{array}$ \\
\hline $\begin{array}{l}\text { Chlormethine } \\
\text { gel initial } \\
\text { application } \\
\text { frequency }\end{array}$ & $\begin{array}{l}\text { Alternative } \\
\text { evenings or } 2 \\
\text { nights/week }\end{array}$ & $\begin{array}{l}\text { 1-2 times/week, } \\
\text { alternating with topical } \\
\text { steroids }\end{array}$ & $\begin{array}{l}\text { Gradually, up to a } \\
\text { maximum of QD, } \\
\text { sometimes with 1-2 } \\
\text { times/week topical } \\
\text { steroids }\end{array}$ & $\begin{array}{l}3 \text { times/week alternating } \\
\text { with topical steroids. If } \\
\text { well tolerated and PR, } \\
\text { increase to QD }\end{array}$ \\
\hline Response time & $\begin{array}{l}\text { 4-6 weeks; } \\
\text { 4-24 months } \\
\text { to achieve CR }\end{array}$ & $\begin{array}{l}1-2 \text { months; } 80 \% \text { of } \\
\text { patients respond }\end{array}$ & NA & $\begin{array}{l}\text { Beginning of response: } \\
\text { 1-2 months. CR: } \\
9-12 \text { months; in some } \\
\text { patients, } 12-15 \text { months } \\
\text { required to achieve CR }\end{array}$ \\
\hline $\begin{array}{r}\text { Incidence of } \\
\text { dermatitis }\end{array}$ & $\begin{array}{l}\text { ICD/ACD: } \\
20-25 \% \text { of } \\
\text { patients in first } \\
6 \text { months }\end{array}$ & $\begin{array}{l}\text { ICD: } \sim 30 \% \\
10 \% \text { develop severe ICD }\end{array}$ & $\begin{array}{l}\text { ICD is the most } \\
\text { commonly diagnosed } \\
\mathrm{AE} \text {, and is usually mild }\end{array}$ & $\begin{array}{l}\text { Mostly ICD ( } 25 \% \text { of cases }) \\
\text { Real ACD rare }\end{array}$ \\
\hline
\end{tabular}


Table 2 continued

\begin{tabular}{|c|c|c|c|c|}
\hline Characteristic & $\begin{array}{l}\text { Penn } \\
\text { Dermatology } \\
\text { Cutaneous } \\
\text { T-Cell } \\
\text { Lymphoma } \\
\text { Clinic, USA }\end{array}$ & $\begin{array}{l}\text { Cutaneous Oncology } \\
\text { Clinic, Columbia } \\
\text { University, USA }\end{array}$ & $\begin{array}{l}\text { Rabin Medical Center, } \\
\text { Israel }\end{array}$ & $\begin{array}{l}\text { Hôpital Saint-Louis, } \\
\text { France }\end{array}$ \\
\hline $\begin{array}{c}\text { Management } \\
\text { strategy for } \\
\text { dermatitis }\end{array}$ & $\begin{array}{l}\text { Temporary } \\
\text { suspension of } \\
\text { treatment } \\
\text { Potent topical } \\
\text { steroids BID for } \\
2-3 \text { weeks }\end{array}$ & $\begin{array}{l}\text { ICD: application of mid- } \\
\text { to-high-potency } \\
\text { ophthalmic steroid } \\
\text { (chlormethine gel } \\
\text { discontinuation if severe } \\
\text { ICD) } \\
\text { ACD: discontinue } \\
\text { chlormethine gel }\end{array}$ & $\begin{array}{l}\text { Mild ICD: avoid } \\
\text { treatment } \\
\text { discontinuation if } \\
\text { possible; temporary } \\
\text { addition of topical } \\
\text { corticosteroids } \\
\text { Moderate-to-severe ICD: } \\
\text { topical steroid plus } \\
\text { temporary reduction or } \\
\text { discontinuation (only } \\
\text { for severe dermatitis) }\end{array}$ & $\begin{array}{l}\text { Moderate-to-severe } \\
\text { dermatitis: chlormethine } \\
\text { gel discontinuation plus } \\
\text { topical steroids; } \\
\text { chlormethine gel } \\
\text { reintroduced after } \\
\text { reactions have } \\
\text { disappeared; and } \\
\text { frequency of application } \\
\text { has progressively increased }\end{array}$ \\
\hline
\end{tabular}

$A C D$ allergic contact dermatitis; $A E$ adverse event; $B I D$ twice daily; $C R$ complete response; $I C D$ irritant contact dermatitis; $M F$ mycosis fungoides; $N A$ data not available; $P R$ partial response; $Q D$ once daily; $S D T$ skin-directed therapy

consistently higher than those for the ointment for the primary endpoint of Composite Assessment of Index Lesion Severity (CAILS), and once-daily (QD) treatment with chlormethine gel met all prespecified criteria for noninferiority. In the efficacy-evaluable population, overall response rates (ORRs) were $77 \%$ and $59 \%$ for the gel and ointment, respectively [15]. Additionally, the $95 \%$ confidence interval of the CAILS score in the efficacy-evaluable population not only exceeded the noninferiority threshold $(\geq 0.75$ ), but also lies entirely above 1 . On the basis of a post hoc approach of switching from noninferiority to superiority testing, these results are consistent with superiority $(p<0.05)$ findings for chlormethine gel.

The gel formulation had a faster time to response (50\% response in 26 weeks) than the ointment (42 weeks). Response rates at 52 weeks were $76 \%$ for the gel and $56 \%$ for the ointment. Maximum response to chlormethine gel treatment occurred between 8 and 10 months, emphasizing the importance of continued treatment and close follow-up of patients to maximize the response potential [15]. A follow- up 7-month extension study evaluated a higher dose of chlormethine gel $(0.04 \%)$ in patients who did not have a complete response (CR) after previously receiving chlormethine gel or ointment for 12 months. In total, $27 \%$ of patients had a confirmed response, which could occur as late as 16 months after initiation of the lower-dose chlormethine treatment [17], thereby reinforcing the value of continued chlormethine treatment.

In the 201 study, $>50 \%$ of patients in each group experienced a skin-related adverse event (AE). Irritant contact dermatitis (ICD) was most common, although this was managed with treatment adjustments, such as suspension or reduction of chlormethine treatment and the use of emollients/oral antihistamines. No treatment-related serious AEs were reported, and there was no evidence of systemic absorption of chlormethine $[15,17]$.

The prospective, observational, noninterventional US-based PROVe trial was designed to provide information on the use of chlormethine gel in a real-world practice setting (NCT02296164). Patients who were diagnosed 
with any stage of MF and were being treated with chlormethine gel in combination with other MF therapies were enrolled. At 12 months, the proportion of stage IA and IB responders (defined as $\geq 50 \%$ reduction from baseline in body surface area [BSA] involvement) was $44 \%$ in patients who received chlormethine plus topical corticosteroids plus other treatment and $45 \%$ in patients who received chlormethine plus other treatment. A peak response occurred at 18 months for patients with stage IA and IB disease in the chlormethine plus other treatment group (67\%). Overall, $28 \%$ of patients experienced a treatment-related $\mathrm{AE}$; the most common skinrelated AEs deemed to be therapy related were dermatitis (12\%), pruritus (7\%), skin irritation (7\%), and erythema (4\%) [45].

Other studies using compounded formulations of chlormethine (ointment or solution) have reported response rates of $58-69 \%$ in patients with early-stage disease [26, 30, 36-38] and $13-53 \%$ in patients with advanced disease $[26,30,37]$. Moreover, one trial has reported a 10 -year overall survival rate of $71 \%$ in patients with mainly T1 or T2 disease (96\%). For those patients who attained a CR with topical chlormethine, a 5-year relapse-free survival rate of $42 \%$ was observed [37]. Another study found that the probability of achieving clinically apparent remission rates at 2 years was $76 \%$ for stage I MF, $45 \%$ for stage II, and $49 \%$ for stage III disease [35].

\section{REAL-WORLD EXPERIENCE OF CHLORMETHINE GEL IN THE MANAGEMENT OF PATIENTS WITH MF (TABLE 2)}

\section{Penn Dermatology Cutaneous T-Cell Lymphoma Clinic}

At the Penn Dermatology Cutaneous T-Cell Lymphoma Clinic (USA), 200 patients with newly diagnosed MF are seen annually; of these, $70 \%$ have early-stage disease. This center uses chlormethine gel as a first-line SDT in patients with early-stage disease for whom topical corticosteroids have failed. It is applied as a localized spot treatment or, for patients with more-extensive BSA involvement, as full-body treatment (from the neck down). In advancedstage disease, chlormethine gel is used as an adjunctive SDT to systemic therapy and other SDTs. For at-home administration, patients must take appropriate precautions to avoid inadvertent mucosal exposure to chlormethine gel in other household members/pets.

Patients are instructed to apply chlormethine gel thinly, initially only every other night or 2 nights/week, then slowly increase the application frequency as tolerance permits, to minimize irritant dermatitis. Patients may apply topical steroids every other day to the same area, but this treatment is eventually tapered if no AEs result from chlormethine gel treatment. Patients using full-body treatment are advised that they may notice new lesions during the first month; however, these are subclinical MF lesions unmasked by chlormethine gel, not necessarily a sign of true disease progression.

In our experience, a response to chlormethine gel treatment can be expected within 4-6 weeks. It takes 4-24 months to achieve a CR; the ORR is $70 \%$, with $10 \%$ of these achieving a CR and $90 \%$ achieving a partial response (PR). ICD or allergic contact dermatitis (ACD) is observed in $20-25 \%$ of patients and occurs mostly within the first 6 months of therapy. When dermatitis or other skin AEs occur, we temporarily discontinue chlormethine gel treatment and apply potent topical steroids to the affected area twice daily (BID) for 2-3 weeks. A "patch test," where chlormethine gel is applied daily to a small unaffected skin area, is then performed. If dermatitis reappears, this is suggestive of ACD, and chlormethine gel is discontinued permanently. If no dermatitis appears, the prior reactions are most likely ICD, and chlormethine gel may be reintroduced slowly with applications every other night or 2 nights/week. This practice of "starting low and going slow" with application frequency is analogous to how we use other SDTs with known irritant effects (e.g., topical retinoids). Patients who experience a moderate-to-severe dermatitis reaction to chlormethine gel may have complete clearance of the original MF 
lesion once the dermatitis is cleared with potent topical steroids, as has been observed in the literature [46].

\section{The Cutaneous Oncology Clinic at Columbia University}

At the Comprehensive Cutaneous Oncology Clinic at Columbia University (USA), a range of disease stages are seen, from early-stage IA and IB MF-CTCL to stage IV disease, including Sézary syndrome. The patients are managed according to published algorithms in a stagebased approach. For patients with early-stage skin-limited disease, topical steroids, narrowband ultraviolet B (NBUVB), and chlormethine gel are the first-line treatments. Based on their schedule, personal preferences, or medical history, and in consultation with their physician, patients choose a therapy that best fits their lifestyle and disease state. Light therapy is an effective way to treat cutaneous manifestations of MF, but it may necessitate frequent visits to the physician's office and may not be convenient for people with busy work and family schedules. Some of the benefits of chlormethine gel include the ability to apply the gel at home, reducing the need for office visits for light therapy in those patients unable to incorporate visits into their daily schedule. Chlormethine gel treatment can continue away from home, provided refrigeration is available, so travel need not interfere with the treatment schedule. Additionally, chlormethine gel is recommended over NBUVB for patients with high risk of melanoma or nonmelanoma skin cancers, including patients with significant personal history of these diseases as well as light skin, numerous atypical nevi, or immunosuppression [47]. Given that a link between chlormethine gel use and development of nonmelanoma skin cancers has been suggested, concurrent NBUVB and chlormethine gel treatment is not typically advised in our patient population [48].

While chlormethine gel is FDA approved for treating stage IA and IB MF in patients who received one prior treatment, we also use chlormethine gel therapy in combination with systemic therapies in more advanced disease, including Sézary syndrome.

At Columbia University, over 350 patients per year are treated with chlormethine gel, all with relatively low toxicity. The main $\mathrm{AE}$ is irritant dermatitis, seen in $\sim 30 \%$ of treated patients. ACD may be observed, and chlormethine gel should be discontinued in these cases. However, ICD is generally well controlled with mid- to high-potency topical steroid use, and chlormethine gel treatment can be continued in most patients. Approximately $10 \%$ of patients develop severe ICD, with lymphomatoid papulosis observed in a few patients; this resolves upon discontinuation of chlormethine gel [49].

Patients generally start chlormethine gel with less frequent applications (one or two times/week, alternating with topical steroids). If the patient can tolerate the gel without ICD or other concerns, the frequency is increased to daily use. In some patients, the gel may be used BID depending on symptoms. In our experience, response rates of up to $80 \%$ have been seen in patients with early-stage disease. Initial response is typically observed 1-2 months after starting treatment, and therapy is continued for 12 months in responders. Frequency can subsequently be reduced during the "maintenance phase," which may last from several months to several years, or chlormethine gel can be discontinued when cutaneous lesions disappear completely. A significant proportion of patients use skin-directed (mostly topical steroids) or systemic agents in combination with chlormethine gel.

\section{The Cutaneous Lymphoma Clinic at Rabin Medical Center}

In Israel, in daily practice the first-line treatment for early-stage MF (after topical steroids) is usually phototherapy, while chlormethine gel is used as a second-line treatment in patients for whom phototherapy has failed or who have developed intolerability. Chlormethine gel as a first-line therapy (after topical steroids) is reserved for patients with early-stage MF who have contraindications to phototherapy (e.g., history of melanoma or multiple nonmelanoma 


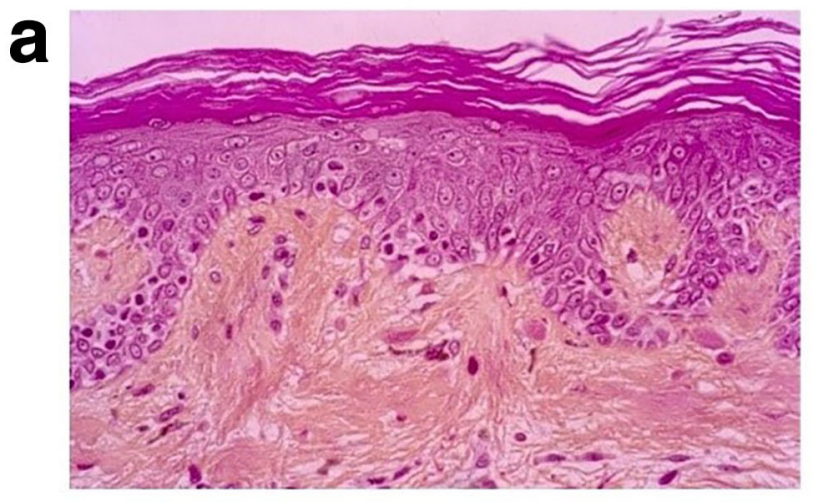

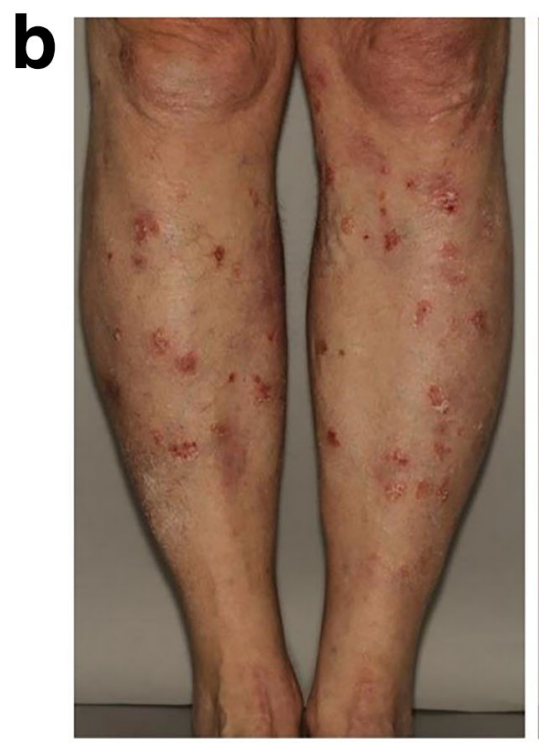

Before

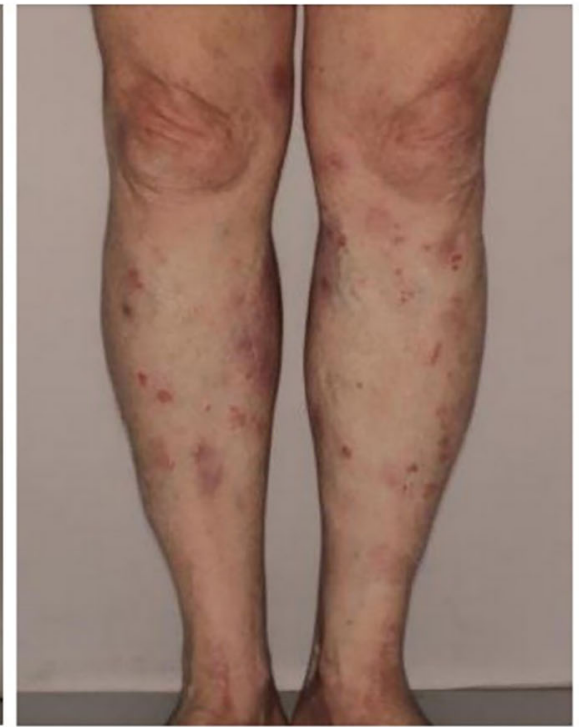

After 3 months

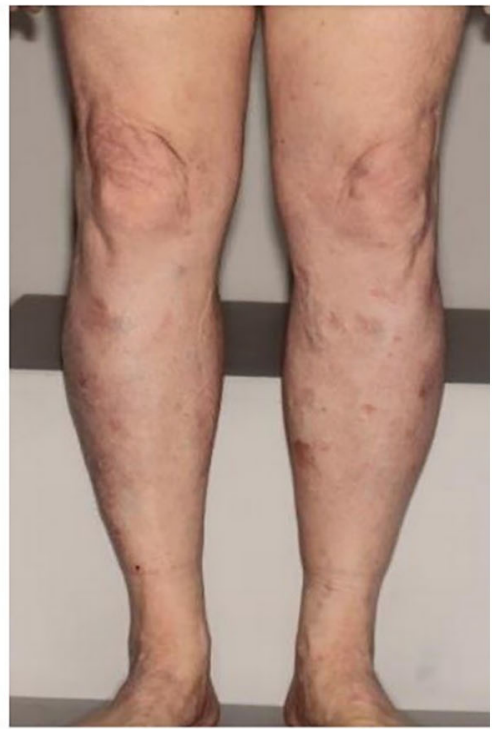

After 6 months

Fig. 1 Patient case images. a Epidermotropism and atypical lymphocytes, diagnostic of mycosis fungoides. $\mathbf{b}$ Skin lesions on the patient's legs before and after 3 and 6 months of once-daily chlormethine gel application

skin cancers) or those who foresee adherence problems to phototherapy. Regional or wholebody application depends on the distribution of lesions and extent of cutaneous involvement. Since chlormethine gel has the potential to cause irritation, treatment initiation involves gradually increasing the application frequency up to the maximal tolerable frequency, but no more than QD, to minimize the occurrence and degree of irritation. The process is similar to that adopted with other topical treatments with irritant potential (e.g., retinoids) [50]. The skin folds and face are generally more susceptible to irritant reactions; hence, the maximal recommended application frequency is usually alternate days.

ICD is the most common AE and is usually mild. In the case of mild irritation, patients may benefit from temporary addition of topical steroids without a change in chlormethine gel application frequency, although in some patients, emollients are sufficient to alleviate symptoms. If irritation is moderate to severe, topical steroid application is advocated alongside temporary reduction (moderate irritation) or temporary discontinuation (severe irritation) of chlormethine gel application. Once irritation is under control or resolved, the application frequency is gradually increased or 
chlormethine gel is reintroduced at the highest tolerable frequency. In many patients, topical steroids may be withdrawn or minimized to once-weekly application. In the case of severe irritation, reintroduction of chlormethine gel may be attempted but is initially limited to a small area to assess tolerability.

The main differential diagnosis of ICD is ACD. Patch tests are not done routinely, and the diagnosis is based solely on clinical judgment. Key diagnostic features are: (1) timing of appearance, with delayed-type hypersensitivity occurring at least 2-4 weeks following treatment initiation versus primary irritation, which may develop as early as a few days after application; (2) distribution, where extension of dermatitis beyond treated areas indicates delayed-type hypersensitivity versus primary irritation, which is localized to treated areas only. ACD is suspected in few patients. If the allergic reaction is mild to moderate, the protocol is the same as for severe irritation. For patients with severe ACD, permanent discontinuation is required. It is important that any type of dermatitis is distinguished clearly from the unmasking effect of chlormethine gel, where new lesions are observed in the treated areas; this is seen in a small fraction of patients and usually occurs during the first month of treatment. Patients should be encouraged to continue with treatment, and whole-body application should be considered.

\section{Hôpital Saint-Louis}

Hôpital Saint-Louis (France) sees $\sim 320$ patients per year with cutaneous lymphomas of any MF stage; 80\% have early-stage and 20\% have advanced-stage disease. In patients with early-stage IA MF, chlormethine gel is prescribed after failure of high-potency corticosteroids, whereas for patients with stage IB, chlormethine gel may be prescribed as a firstline therapy, particularly in patients for whom phototherapy is not possible or contraindicated. In patients with late-stage disease, chlormethine gel is used in combination with systemic treatments when insufficient effect is observed on patch or plaque lesions. Response to chlormethine gel may occur 9 months after treatment initiation, but in some patients a period of 12 or 15 months may be required to achieve remission. In our experience, $19 \%$ of patients achieve a CR, and $66 \%$ have a PR.

The most common $\mathrm{AE}$ is skin reactions, mostly contact irritation versus real allergic dermatitis. When severe skin reactions are observed (e.g., moderately severe to severe dermatitis), chlormethine gel is discontinued and topical steroids are prescribed. Once the reactions have disappeared, chlormethine gel may be applied to a limited zone with persisting lesions on the trunk or the limb, with a reduced schedule (one or two times/week). If the patient presents with real sensitization, contact allergy will develop on the limited area, thereby indicating the patient has a true allergy, and chlormethine gel is contraindicated. In most patients, however, this limited application is well tolerated, and it is possible to apply chlormethine gel to the whole skin, up to three times/week, and often every day. Real patch testing to determine whether the response is ICD or ACD may be very informative in such situations.

A 58-year-old male with a history of melanoma on his back presented with stage IB MF. The patient had disseminated pruriginous erythematosquamous patches and plaques, although there were no adenopathies or blood involvement. A cutaneous biopsy demonstrated a band-like infiltrate with epidermotropism and atypical lymphocytes, and the patient was diagnosed with stage IB MF. Treatment with topical clobetasol yielded no response, while treatment with phototherapy was not possible due to the history of melanoma. Consequently, this patient was treated with chlormethine gel QD. Due to the dissemination of lesions, chlormethine gel was applied to the whole body, except for the face and scalp, where no lesions were present. After 9 months of chlormethine gel treatment, the patient was in full remission and treatment was stopped (Fig. 1). 


\section{CONCLUSIONS}

Chlormethine gel is a therapeutic option for patients with MF skin lesions, and a range of retrospective, prospective, and observational clinical data supports its use in all disease stages. Its validity as a treatment is supported by international guidelines, which all recommend chlormethine gel as a first-line treatment for patients with early-stage MF. In later stages of $\mathrm{MF}$, systemic treatments are usually indicated and prescribed, although patch and plaque lesions in these patients may be only partially responsive to systemic treatments; the addition of topical treatments, such as chlormethine gel, may be very useful in such cases. Moreover, chlormethine gel may be important as an adjunctive therapy in patients with late-stage disease (especially for persisting patches and plaques) to palliate symptoms and to improve the overall response and as a maintenance treatment since systemic therapies do not typically result in durable CRs.

Indeed, experience from clinical practice in the USA, Israel, and France has shown that chlormethine gel is used both as an SDT (often in the first line) in early-stage MF and as an adjunctive therapy in advanced-stage disease. The strategies employed by the centers demonstrate that emergent cutaneous reactions can be managed if the appropriate protocols are followed. Time to response varies slightly between centers, perhaps reflecting the diversity of patients who were seen (Table 2). ICD is the most frequently observed form of dermatitis, and all centers use topical steroids to manage this $\mathrm{AE}$, although discontinuing chlormethine treatment may be required for severe reactions.

Efforts are ongoing to gain a more in-depth understanding of the utility of chlormethine gel in patients with MF and the nature of the emergent skin reactions. The PROVe trial found that chlormethine gel is an effective treatment across all disease stages [45]. No chlormethine gel-related serious AEs occurred in the study, and the reported emergent skin-related AEs were manageable and less prevalent than in the pivotal clinical trial [15], possibly because of frequent dose adjustments and the co- administration of corticosteroids, which reflect the real-world experience reported herein.

The Mechlorethamine Induced Contact Dermatitis Avoidance Study (MIDAS; NCT03380026), which evaluated the incidence and severity of contact dermatitis following treatment with chlormethine gel alone or in combination with triamcinolone ointment in patients with MF, aimed to gain a greater understanding of chlormethine-related contact dermatitis. The study found that contact dermatitis with and without hypersensitivity responses was seen, and histopathology revealed a superficial and deep lymphocytic infiltrate with spongiosis and eosinophils similar to arthropod assault $[43,44]$. Evaluation of the patient samples is ongoing to provide more information about the nature of the skin reactions, which should further help to guide management of patients who develop contact dermatitis. Additional information that may be used to guide treatment and manage contact dermatitis in patients who receive chlormethine gel may come from the REACH trial (Study to Determine the Aetiology of Chlormethine Gel Induced-skin Drug Reaction in Early-stage Mycosis Fungoides Cutaneous T Cell Lymphoma; NCT04218825), which is currently recruiting.

In conclusion, chlormethine gel is an effective treatment for patients with all stages of MF. While contact dermatitis is an emergent skinrelated $\mathrm{AE}$, it can be managed effectively in most cases if the appropriate strategies are in place.

\section{ACKNOWLEDGMENTS}

Funding. Funding for this review the journal's and Rapid Service Fee were funded by Helsinn Healthcare SA, Lugano, Switzerland.

Medical Writing and/or Editorial Assistance. Editorial and medical writing assistance was provided by Joanne Franklin, PhD, CMPP, from Aptitude Health, The Hague, The Netherlands, funded by Helsinn Healthcare SA, Lugano, Switzerland. 
Authorship. All named authors meet the International Committee of Medical Journal Editors (ICMJE) criteria for authorship for this article, take responsibility for the integrity of the work as a whole, and have given their approval for this version to be published.

Authorship Contributions. All authors equally contributed to the concept, design, and drafting of the manuscript.

Disclosures. Larisa J. Geskin has received research support from and was Principal Investigator for BMS, Galderma, Helsinn, Innate Pharma, Johnson \& Johnson, Kyowa Kirin, Mallinckrodt, Merck, miRagen, Soligenix, and Stratpharma. She was also a speakers' bureau member for Helsinn, a scientific advisory board member for Helsinn, Kyowa Kirin, Mallinckrodt, Recordati, Regeneron Pharmaceuticals, and Takeda, and has consulted for Regeneron Pharmaceuticals and Sanofi. Martine Bagot is a scientific advisory board member for Helsinn/ Recordati, Innate Pharma, Kyowa Kirin, and Takeda. Emmilia Hodak was a scientific advisory board member for Actelion, Helsinn, and Takeda and a speakers' bureau member for Helsinn, Rafa, and Takeda. Ellen J. Kim has received clinical trial grants from Galderma, Innate, Kyowa Kirin, and Soligenix. She has also consulted for Galderma and Helsinn.

Compliance with Ethics Guidelines. This article is based on previously conducted studies and does not contain any new studies with human participants or animals performed by any of the authors. Informed consent was provided by the patient whose case was included.

Open Access. This article is licensed under a Creative Commons Attribution-NonCommercial 4.0 International License, which permits any non-commercial use, sharing, adaptation, distribution and reproduction in any medium or format, as long as you give appropriate credit to the original author(s) and the source, provide a link to the Creative Commons licence, and indicate if changes were made. The images or other third party material in this article are included in the article's Creative Commons licence, unless indicated otherwise in a credit line to the material. If material is not included in the article's Creative Commons licence and your intended use is not permitted by statutory regulation or exceeds the permitted use, you will need to obtain permission directly from the copyright holder. To view a copy of this licence, visit http://creativecommons.org/licenses/by$\mathrm{nc} / 4.0 /$.

\section{REFERENCES}

1. Diamandidou E, Cohen PR, Kurzrock R. Mycosis fungoides and Sezary syndrome. Blood. 1996;88: 2385-409.

2. van Doorn R, Van Haselen CW, van Voorst Vader PC, et al. Mycosis fungoides: disease evolution and prognosis of 309 Dutch patients. Arch Dermatol. 2000;136:504-10.

3. Lovgren ML, Scarisbrick JJ. Update on skin directed therapies in mycosis fungoides. Chin Clin Oncol. 2019;8:7.

4. Zackheim HS, Amin S, Kashani-Sabet M, McMillan A. Prognosis in cutaneous T-cell lymphoma by skin stage: long-term survival in 489 patients. J Am Acad Dermatol. 1999;40:418-25.

5. de Coninck EC, Kim YH, Varghese A, Hoppe RT. Clinical characteristics and outcome of patients with extracutaneous mycosis fungoides. J Clin Oncol. 2001;19:779-84.

6. Kim YH, Liu HL, Mraz-Gernhard S, Varghese A, Hoppe RT. Long-term outcome of 525 patients with mycosis fungoides and Sezary syndrome: clinical prognostic factors and risk for disease progression. Arch Dermatol. 2003;139:857-66.

7. Scarisbrick JJ, Prince HM, Vermeer $\mathrm{MH}$, et al. Cutaneous Lymphoma International Consortium study of outcome in advanced stages of mycosis fungoides and Sézary syndrome: effect of specific prognostic markers on survival and development of a prognostic model. J Clin Oncol. 2015;33:3766-73.

8. Al Hothali GI. Review of the treatment of mycosis fungoides and Sézary syndrome: a stage-based approach. Int J Health Sci (Qassim). 2013;7:220-39.

9. DeSimone JA, Sodha P, Ignatova D, Dummer R, Cozzio A, Guenova E. Recent advances in primary cutaneous T-cell lymphoma. Curr Opin Oncol. 2015;27:128-33. 
10. Willemze R, Hodak E, Zinzani PL, Specht L, Ladetto M, ESMO Guidelines Committee. Primary cutaneous lymphomas: ESMO Clinical Practice Guidelines for diagnosis, treatment and follow-up. Ann Oncol. 2018;29:iv30-40.

11. Trautinger F, Eder J, Assaf C, et al. European Organisation for Research and Treatment of Cancer consensus recommendations for the treatment of mycosis fungoides/Sézary syndrome-update 2017. Eur J Cancer. 2017;77:57-74.

12. National Comprehensive Cancer Network. NCCN Clinical Practice Guidelines (NCCN Guidelines ${ }^{\circledR}$ ). Primary cutaneous lymphomas. Version 2.2020. https://www.nccn.org/professionals/physician_gls/ pdf/primary_cutaneous.pdf. Accessed 1 Feb 2021.

13. Gilson D, Whittaker SJ, Child FJ, et al. British Association of Dermatologists and U.K. Cutaneous Lymphoma Group guidelines for the management of primary cutaneous lymphomas 2018. Br J Dermatol. 2019;180:496-526.

14. Zackheim HS, Kashani-Sabet M, Amin S. Topical corticosteroids for mycosis fungoides. Experience in 79 patients. Arch Dermatol. 1998;134:949-54.

15. Lessin SR, Duvic M, Guitart J, et al. Topical chemotherapy in cutaneous T-cell lymphoma: positive results of a randomized, controlled, multicenter trial testing the efficacy and safety of a novel mechlorethamine, $0.02 \%$, gel in mycosis fungoides. JAMA Dermatol. 2013;149:25-32.

16. Breneman D, Duvic M, Kuzel T, Yocum R, Truglia J, Stevens VJ. Phase 1 and 2 trial of bexarotene gel for skin-directed treatment of patients with cutaneous T-cell lymphoma. Arch Dermatol. 2002;138: 325-32.

17. Kim YH, Duvic M, Guitart J, Lessin SR. Tolerability and efficacy of mechlorethamine $0.04 \%$ gel in CTCL (mycosis fungoides) after initial treatment with topical mechlorethamine $0.02 \%$ gel. Presented at: 6th Annual T-cell Lymphoma Forum; January 23-25, 2014; San Francisco, CA, USA.

18. Ledaga [summary of product characteristics]. London, UK: Actelion Registration Ltd; 2017.

19. ATU Rapport de Synthese pour Valchlor/Ledaga ${ }^{\circledR}$. Rapport nr. 9, version 1.0. Helsinn Birex Pharmaceuticals Ltd. Dublin, Ireland. 2019.

20. Osborne DW, Musakhanian J. Skin penetration and permeation properties of Transcutol®-neat or diluted mixtures. AAPS PharmSciTech. 2018;19: 3512-33.

21. Ritschel WA, Ye W, Buhse L, Reepmeyer JC. Stability of the nitrogen mustard mechlorethamine in novel formulations for dermatological use. Int $\mathrm{J}$ Pharm. 2008;362:67-73.

22. Sullivan DW Jr, Gad SC, Julien M. A review of the nonclinical safety of Transcutol ${ }^{\circledR}$, a highly purified form of diethylene glycol monoethyl ether (DEGEE) used as a pharmaceutical excipient. Food Chem Toxicol. 2014;72:40-50.

23. Ashland Inc. Klucel ${ }^{\mathrm{TM}}$ hydroxypropylcellulose. Physical and chemical properties. 2017. https:// www.ashland.com/file_source/Ashland/Product/Do cuments/Pharmaceutical/PC_11229_Klucel_HPC. pdf. Accessed 1 Feb 2021.

24. Soo VWC, Kwan BW, Quezada H, et al. Repurposing of anticancer drugs for the treatment of bacterial infections. Curr Top Med Chem. 2017;17:1157-76.

25. Molin L, Thomsen K, Volden G, et al. Aspects of the treatment of mycosis fungoides. A report from the Scandinavian Mycosis Fungoides Study Group. Cutis. 1980;25(155-7):160-1.

26. Vonderheid EC, Tan ET, Kantor AF, Shrager L, Micaily B, Van Scott EJ. Long-term efficacy, curative potential, and carcinogenicity of topical mechlorethamine chemotherapy in cutaneous T cell lymphoma. J Am Acad Dermatol. 1989;20:416-28.

27. Lindahl LM, Fenger-Gron M, Iversen L. Topical nitrogen mustard therapy in patients with mycosis fungoides or parapsoriasis. J Eur Acad Dermatol Venereol. 2013;27:163-8.

28. Jennings T, Duffy R, Gochoco A, et al. Valchlor maintenance therapy for patients with mycosis fungoides who received low dose total skin electron beam treatment. Chin Clin Oncol. 2019;8:13.

29. Price NM, Hoppe RT, Constantine VS, Fuks ZY, Farber EM. The treatment of mycosis fungoides: adjuvant topical mechlorethamine after electron beam therapy. Cancer. 1977;40:2851-3.

30. Vonderheid EC, Van Scott EJ, Wallner PE, Johnson WC. A 10-year experience with topical mechlorethamine for mycosis fungoides: comparison with patients treated by total-skin electron-beam radiation therapy. Cancer Treat Rep. 1979;63:681-9.

31. Price NM, Hoppe RT, Deneau DG. Ointment-based mechlorethamine treatment for mycosis fungoides. Cancer. 1983;52:2214-9.

32. Ramsay DL, Parnes RE, Dubin N. Response of mycosis fungoides to topical chemotherapy with mechlorethamine. Arch Dermatol. 1984;120: 1585-90.

33. Zachariae $\mathrm{H}$, Thestrup-Pedersen $\mathrm{K}$, Søgaard $\mathrm{H}$. Topical nitrogen mustard in early mycosis 
fungoides. A 12-year experience. Acta Derm Venereol. 1985;65:53-8.

34. Hoppe RT, Abel EA, Deneau DG, Price NM. Mycosis fungoides: management with topical nitrogen mustard. J Clin Oncol. 1987;5:1796-803.

35. Ramsay DL, Halperin PS, Zeleniuch-Jacquotte A. Topical mechlorethamine therapy for early stage mycosis fungoides. J Am Acad Dermatol. 1988;19: 684-91.

36. Foulc P, Evrard V, Dalac S, et al. Evaluation of a 1-h exposure time to mechlorethamine in patients undergoing topical treatment. $\mathrm{Br} \mathrm{J}$ Dermatol. 2002;147:926-30.

37. Kim YH, Martinez G, Varghese A, Hoppe RT. Topical nitrogen mustard in the management of mycosis fungoides: update of the Stanford experience. Arch Dermatol. 2003;139:165-73.

38. de Quatrebarbes J, Estève E, Bagot M, et al. Treatment of early-stage mycosis fungoides with twiceweekly applications of mechlorethamine and topical corticosteroids: a prospective study. Arch Dermatol. 2005;141:1117-20.

39. Licata AG, Wilson LD, Braverman IM, Feldman AM, Kacinski BM. Malignant melanoma and other second cutaneous malignancies in cutaneous T-cell lymphoma. The influence of additional therapy after total skin electron beam radiation. Arch Dermatol. 1995;131:432-5.

40. Estève $\mathrm{E}$, Bagot $\mathrm{M}$, Joly $\mathrm{P}$, et al. A prospective study of cutaneous intolerance to topical mechlorethamine therapy in patients with cutaneous T-cell lymphomas. French Study Group of Cutaneous Lymphomas. Arch Dermatol. 1999;135:1349-53.

41. Lindahl LM, Fenger-Grøn M, Iversen L. Secondary cancers, comorbidities and mortality associated with nitrogen mustard therapy in patients with mycosis fungoides: a 30-year population-based cohort study. Br J Dermatol. 2014;170:699-704.

42. Kim EJ, Geskin L, Guitart J, et al. Real-world experience with mechlorethamine gel in patients with mycosis fungoides-cutaneous lymphoma: preliminary findings from a prospective observational study. J Am Acad Dermatol. 2020;83:928-30.

43. Gilmore ES, Alexander-Savino CV, Chung CG, Poligone $\mathrm{B}$. Incidence and types of contact dermatitis after chlormethine gel treatment in patients with mycosis fungoides-type cutaneous T-cell lymphoma: The MIDAS study. Presented at the 4th World Congress of Cutaneous Lymphomas. 12-14 February 2020; Barcelona, Spain. Abstract Y-04. Available at http://wcclbarcelona2020.com/ images/site/PROTEGIDO/Abstracts_WCCl_2020_

DIGITAL.pdf. Accessed 1 Feb 2021.

44. Alexander-Savino CV, Chung CG, Gilmore ES, Poligone B. Molecular signature patterns related to the development of contact dermatitis in patients with mycosis fungoides-type cutaneous T-cell lymphoma treated with chlormethine gel. Presented at the 4th World Congress of Cutaneous Lymphomas. 12-14 February 2020; Barcelona, Spain. Abstract 026. Available at http://wcclbarcelona2020.com/ images/site/PROTEGIDO/Abstracts_WCCl_2020_ DIGITAL.pdf. Accessed 1 Feb 2021.

45. Kim EJ, Guitart J, Querfeld C, et al. The PROVe study: US real-world experience with chlormethine/ mechlorethamine gel in combination with other therapies for patients with mycosis fungoides cutaneous T-cell lymphoma. Am J Clin Dermatol. 2021. https://doi.org/10.1007/s40257-021-00591-x.

46. Vonderheid EC, Ekbote SK, Kerrigan K, et al. The prognostic significance of delayed hypersensitivity to dinitrochlorobenzene and mechlorethamine hydrochloride in cutaneous T cell lymphoma. J Invest Dermatol. 1998;110:946-50.

47. Johnson MM, Leachman SA, Aspinwall LG, et al. Skin cancer screening: recommendations for datadriven screening guidelines and a review of the US Preventive Services Task Force controversy. Melanoma Manag. 2017;4:13-37.

48. Du Vivier A, Vonderheid EC, Van Scott EJ, Urbach F. Mycosis fungoides, nitrogen mustard and skin cancer. Br J Dermatol. 1978;99:61-3.

49. Trager MH, Chen C, Husain S, Geskin LJ. Nitrogen mustard gel-induced inflammation triggers lymphomatoid papulosis in patients with mycosis fungoides. J Dermatol. 2020;47:546-50.

50. Latkowski JA, Heald P. Strategies for treating cutaneous T-cell lymphoma: part 1: remission. J Clin Aesthet Dermatol. 2009;2:22-7. 